Proc. Estonian Acad. Sci. Geol., 1998, 47, 2, 77-85

\title{
REVISION OF THE ORDOVICIAN AND SILURIAN RAMPHOPRIONID POLYCHAETES FROM SEVERNAYA ZEMLYA, RUSSIAN ARCTIC
}

\author{
Olle HINTS
}

Institute of Geology at Tallinn Technical University, Estonia pst. 7, EE-0001 Tallinn, Estonia; e-mail: olle@gi.ee

Received 20 October 1997, in revised form 13 November 1997

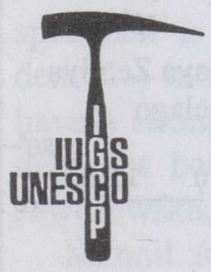

IGCP Project 406

Circum-Arctic

Palacozoic Vertebrates

Abstract. In this paper the Ordovician and Silurian ramphoprionids from Severnaya Zemlya (collection of Männil \& Zaslavskaya, 1985, Trudy Instituta geologii i geofiziki SO AN SSSR, 615) are revised. The confusion regarding the holotype of Pararamphoprion? nordicus Männil \& Zaslavskaya, 1985 is corrected by designation of the appropriate lectotype. Two new species are described, one of which (Pararamphoprion? sp. A) was previously included in P.? nordicus. $P$.? matusevichi sp. nov. predominates over other jawed polychaetes in the Ashgillian samples, whereas in the Silurian samples ramphoprionids are found only rarely. This suggests that the role of ramphoprionids decreased after the Ordovician in Severnaya Zemlya, like it seems to have occurred in Baltoscandia. Affinities and exact generic position of the three ramphoprionids in question remain uncertain for the time being.

Key words: scolecodonts, polychaete jaws, Ordovician, Silurian, Severnaya Zemlya.

\section{INTRODUCTION}

Jaws of ramphoprionid polychaetes are frequently found among organic microfossils in the Ordovician and Silurian limestones. Nevertheless, the family Ramphoprionidae is rather poorly studied and several species have been left undescribed (Kielan-Jaworowska, 1966, p. 108) or have not been revised after the initial description under single-element classification by, e.g., Hinde (1879), Stauffer (1933), and Eller $(1942,1945)$. In a pioneering study on the polychaete jaws of northern Russia, Männil \& Zaslavskaya (1985) described 17 Silurian species including one new ramphoprionid. They introduced the genus Para- 
ramphoprion with Pararamphoprion urbaneki (Kielan-Jaworowska, 1966) as the type species and described a new species, $P$. nordicus. Unfortunately the material of Männil \& Zaslavskaya (1985) is not well preserved. The authors did not find any fused jaw apparatuses but reconstructed them from detached scolecodonts. In spite of the fact that most of these reconstructions can be considered successful, a re-examination of the collection, particularly the type material of $P$. nordicus, and the paper itself has revealed several important aspects which are discussed in this study. The collection is deposited at the Institute of Geology at Tallinn Technical University (abbreviated GI). The material is derived from 73 samples (11 of which yielded jaws of ramphoprionids) from Ashgill to late Wenlock or early Ludlow, from six outcrops in Severnaya Zemlya (Figs. 1 and 2). All samples were collected by Peep Männik for conodonts (Männik, 1982). For geological and stratigraphical background see, e.g., Egiazarov (1959), Klubov et al. (1980), Menner et al. (1979), Kurik et al. (1982), and Männik (1982). The descriptive terminology follows Jansonius \& Craig (1971).

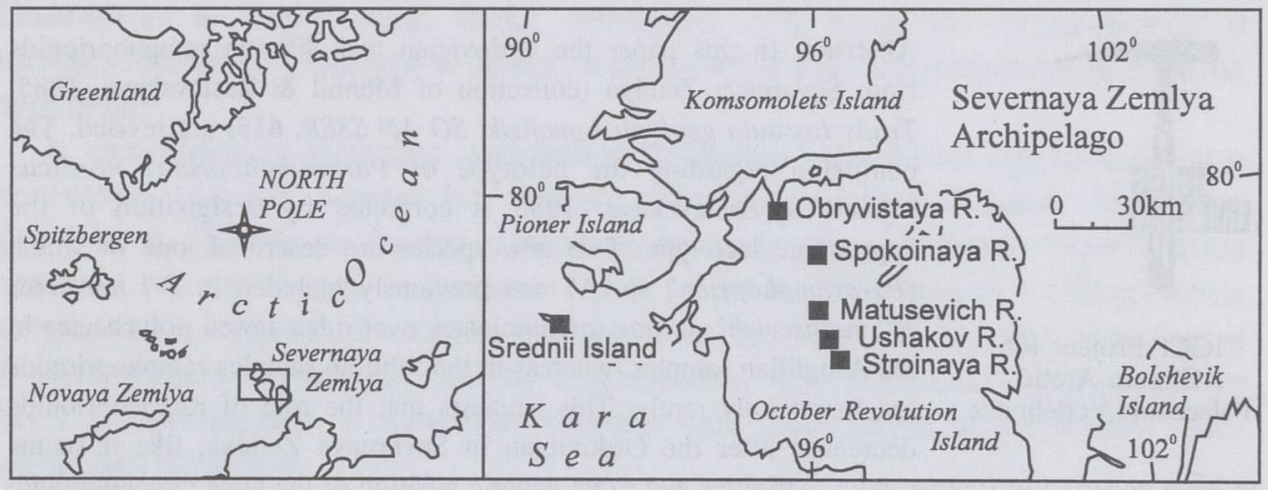

Fig. 1. Sketch map of the study area and sampling localities.

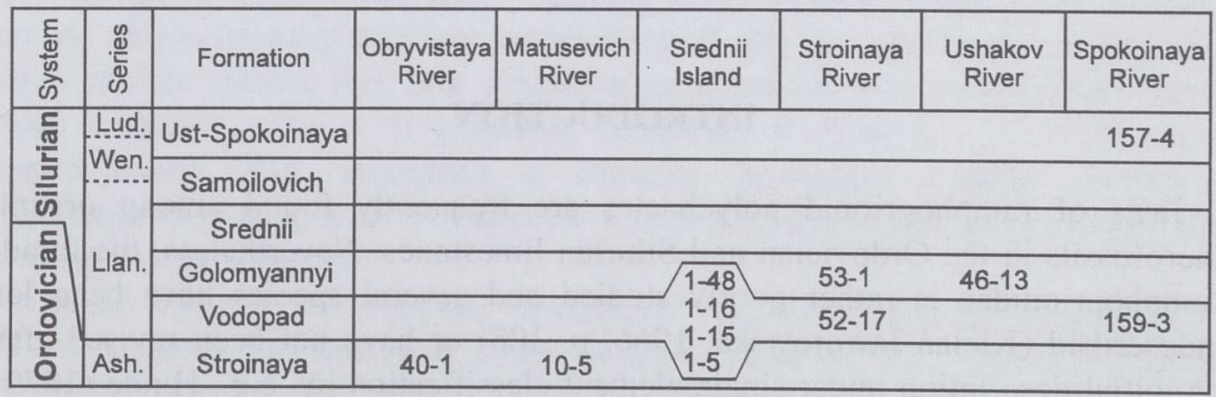

Fig. 2. Numbers, ages, and geographical positions of the samples which yield jaws of ramphoprionid polychaetes. Ash., Ashgill; Llan., Llandovery; Wen., Wenlock; Lud., Ludlow. For the locality map see Fig. 1. 


\title{
SYSTEMATIC PALAEONTOLOGY
}

\author{
Class POLYCHAETA Grube, 1850 \\ Order EUNICIDA Dales, 1963 \\ Family RAMPHOPRIONIDAE Kielan-Jaworowska, 1966
}

Genus Pararamphoprion Männil \& Zaslavskaya, 1985

\section{Type species. Pararamphoprion urbaneki (Kielan-Jaworowska, 1966).}

Remarks. Morphological differences between $P$. urbaneki and the type species of Ramphoprion, $R$. elongatus, were pointed out already by Kielan-Jaworowska (1966). P. urbaneki differs from $R$. elongatus in having broader posterior maxillae (MI), longer myocoele openings, and longer shank. The greatest width of left MI located at about midlength (compared to posterior from midlength in $R$. elongatus) and shorter carriers with rounded posterior parts are characteristic of $P$. urbaneki. However, presumable lack of lateral teeth in Pararamphoprion, mentioned by Männil \& Zaslavskaya, must be regarded uncertain since the type specimen is not complete. Besides, the continuous decrease in the size of denticles in MI, as stated in the same paper, is misleading as $P$. urbaneki may have a strongly differentiated dentary in the left MI with about five very small denticles between the larger ones in the anterior part of the ridge (KielanJaworowska, 1966; Plate, figs. 1, 2 in this paper).

Männil \& Zaslavskaya (1985) assigned P. nordicus (including the species described herein as Pararamphoprion? sp. A) without any doubt to Pararamphoprion. In addition, they noticed that several undescribed species in the Ordovician of East Baltic belong to the same genus. From the three species described in this paper, P.? matusevichi sp. nov. shows the greatest morphological similarity to $P$. urbaneki. On the other hand, $P$. ? matusevichi is rather similar to $P$.? nordicus. It is likely that they belong to a particular evolutionary lineage, in which the jaws have evolved by elongation of the covers in both MI, elongation of the ramus, and a decrease in the number of denticles. Right MI of Pararamphoprion? sp. A are, however, rather different from the corresponding jaws of the above-mentioned species and show some resemblance to $R$. elongatus. Affinities of the species in question are confused also because of the single carrier and the second maxillae which were assigned to P.? nordicus by Männil \& Zaslavskaya (1985, pl. 16, fig. 7v and pl. 16, figs. 6d, 7a, respectively).

The material is not rich, no fused apparatuses have been found, and only posterior parts of apparatuses of two species can be reconstructed. Moreover, according to some new data (Eriksson, 1997, also pers. comm.), there may appear some problems concerning the generic name Pararamphoprion, which may possibly turn out to be a younger synonym of Protarabellites Stauffer, 1933 a genus established previously on the basis of form taxonomy. For these reasons I 
have assigned all three species described herein tentatively to Pararamphoprion. Their correct generic position remains uncertain for the time being and is addressed for further study.

\title{
Pararamphoprion? nordicus Männil \& Zaslavskaya, 1985
}

\author{
Plate, figs. 3-8
}

1985 Pararamphoprion nordicus sp. nov. Männil \& Zaslavskaya, pp. 114-115, pl. 16, fig. $6 b$ (partim).

Lectotype. Right posterior maxilla, GI Sc 738/36, figured by Männil \& Zaslavskaya (1985) in pl. 16, fig. 6b.

Type locality. Spokoinaya River, Severnaya Zemlya, Russian Arctic.

Type horizon. Ust-Spokoinaya Formation, late Wenlock or early Ludlow (sample 157-4).

Material. Three right MI and four left MI from samples 1-15, 1-48, 46-13, 53-1, 159-3.

\section{PLATE}

Figs. 1, 2. Pararamphoprion urbaneki (Kielan-Jaworowska, 1966): 1, left MI, GI Sc 61, dorsal view, Leningrad district, Apraksin Bor (17) drill core, depth 111.2 m, Caradoc, x 45; 2, same, ventral view.

Figs. 3-8. Pararamphoprion? nordicus Männil \& Zaslavskaya, 1985: 3, left MI, GI Sc 91, dorsal view, sample 53-1, Stroinaya River, Golomyannyi Formation, x 37; 4, same, ventral view; 5, left MI, GI Sc 92, sample 46-13, Ushakov River, Golomyannyi Formation, x 115; 6, right MI, GI Sc 93, dorsal view, sample 1-15, Srednii Island, Vodopad Formation, x 80; 7, right MI, sketch drawing, ventral view; 8 , right $\mathrm{MI}$, sketch drawing, right lateral view.

Figs. 9-11. Pararamphoprion? sp. A: 9, right MI, GI 738/38, dorsal view, sample 157-4, Spokoinaya River, Ust-Spokoinaya Formation, x 60; 10, right MI, GI 738/37, ventral view, sample 157-4, Spokoinaya River, Ust-Spokoinaya Formation, x 60; 11, right MI, sketch drawing, right lateral view.

Figs. 12-20. Pararamphoprion? matusevichi sp. nov.: 12, left MI, GI Sc 95, ventral view, sample 10-5, Matusevich River, Stroinaya Formation, x 80; 13, left MI, GI Sc 94 (holotype), dorsal view, sample 10-5, Matusevich River, Stroinaya Formation, x 60; 14, basal plate, GI Sc 99, ventral view, sample 40-1, Obryvistaya River, Stroinaya Formation, x 50; 15, right MI, GI Sc 96, dorsal view, sample 10-5, Matusevich River, Stroinaya Formation, x 115; 16, right MI, GI Sc 100, dorsal view, sample 10-5, Matusevich River, Stroinaya Formation, x 70; 17, right MI, GI Sc 97, ventral view, sample 10-5, Matusevich River, Stroinaya Formation, x 100; 18, basal plate, same as 14, dorsal view; 19, right MI, sketch drawing, right lateral view; 20, right MI, GI Sc 98, dorsal view, sample 10-5, Matusevich River, Stroinaya Formation, x 100. 


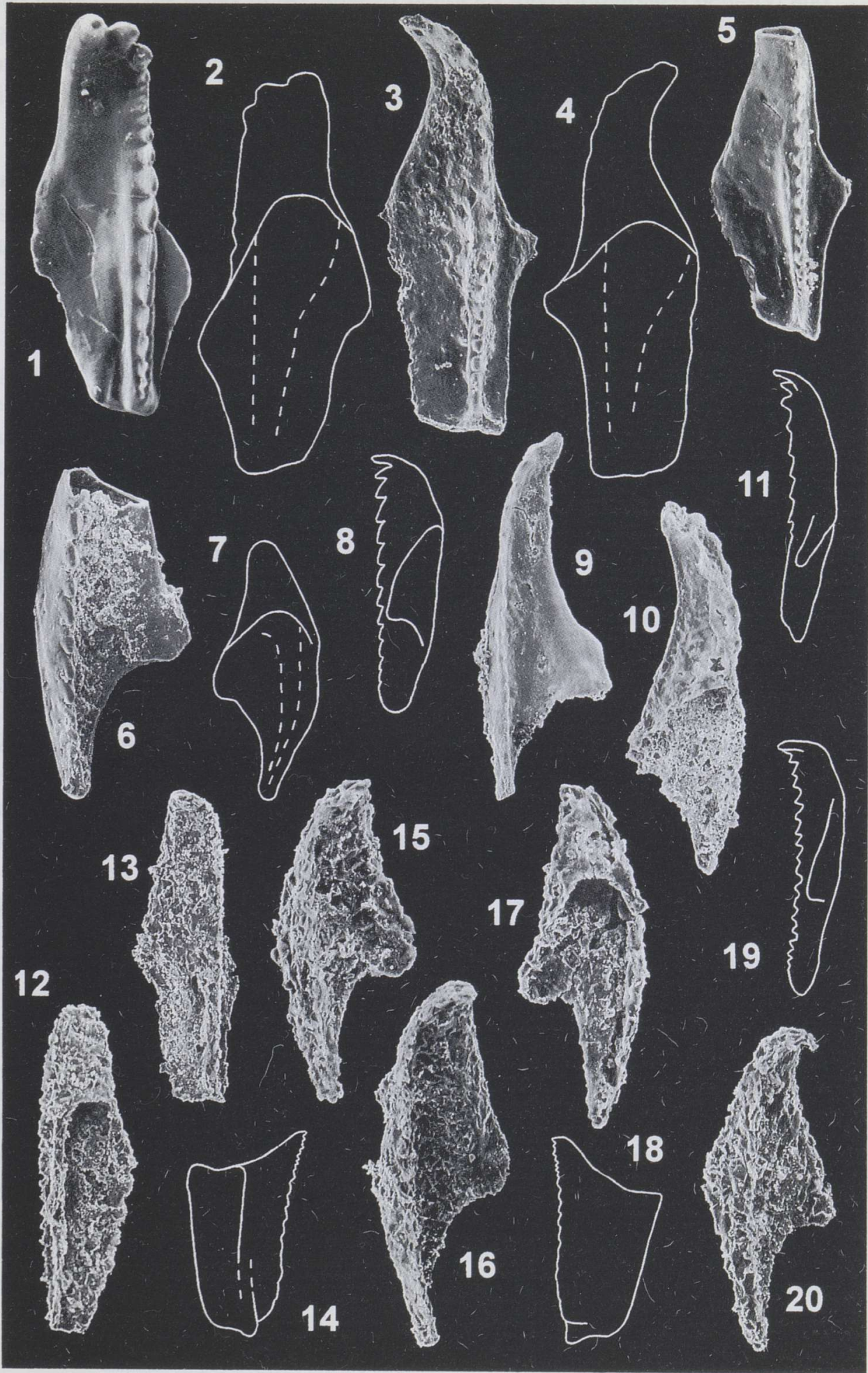



Emended diagnosis. P.? nordicus differs from $P$. urbaneki in having more closed myocoele openings in MI, smaller denticles, undifferentiated dentary, and longer and crest-like inner wing; maximum lateral extension of inner wing is located more anteriorly in left MI. It differs from Ramphoprion elongatus in having stouter MI, shorter cover in MI, longer shank, less and smaller denticles, and maximum lateral extension of inner wing in left MI, located more anteriorly.

Description. Right MI: Length 0.5-1.1 mm, length/width ratio 2.5-2.6; dentary consists of 14-15 continuously decreasing denticles; ramus extends to $0.62-0.64$ of jaw length from anterior; outer margin between anterior part and tip of ramus is slightly incurved; cover occupies $0.3-0.32$ of jaw length.

Left MI: Length $0.44-1.7 \mathrm{~mm}$, length/width ratio 2.6-2.8; dentary consists of 13-16 smoothly decreasing denticles and is curved outwards anteriorly; outer wing is triangular, its greatest width is located at $0.48-0.51$ of jaw length from anterior; inner wing is long, its somewhat pointed maximum lateral extension is located at $0.51-0.54$ of jaw length from anterior; posterior margin is directed postero-medially and forms $0.46-0.57$ of jaw width; cover reaches to $0.39-0.41$ of jaw length.

Remarks. Männil \& Zaslavskaya (1985, p. 114) cited the specimen No.738/39 as the holotype. The figures of the type specimen, referred to in the same chapter, display two other specimens, left and right MI (Nos. 738/35 and 738/36, respectively). In the explanation to the figures (ibid., p. 129) these specimens are called holotypes, whereas the data on the specimen No. $738 / 39$ do not contain this notice. However, the holotype of a species must represent one animal (ICZN, 1985, Article 73), that means, it can be one certain jaw plate, unless several jaws are attached, constituting an apparatus. In the present case, three detached jaws, derived by no means from one animal, are marked as holotypes. One of them (left MII No. 738/39) is of uncertain affinity (see discussion below), the second (left MI No. 738/35) does not belong to Ramphoprionidae, but to Polychaetaspidae and only the third jaw (right MI No. 738/36) definitely belongs to Ramphoprionidae. Since the rules of designating a holotype (ICZN, 1985, Article 73) were violated, none of these jaws can be considered as the holotype, but according to Article 74, the lectotype can be selected from the type series (preferring the specimens published by the original author). The right MI No. 738/36, figured by Männil \& Zaslavskaya (1985) in pl. 16, fig. 6b, is appropriate for the lectotype of $P$.? nordicus.

The basal plate (No. 738/41) and the carrier (No. 738/42) figured by Männil \& Zaslavskaya (1985) in pl. 16, figs. $7 \mathrm{~b}$ and $7 \mathrm{v}$, respectively, belong to ramphoprionids, but as two similar species occur in the same samples, they should not be assigned to P.? nordicus. Furthermore, the carrier with its elongated form and tapering posterior part resembles $R$. elongatus rather than P. urbaneki. Männil \& Zaslavskaya (1985) also described two left second 

Emended diagnosis. P.? nordicus differs from $P$. urbaneki in having more closed myocoele openings in MI, smaller denticles, undifferentiated dentary, and longer and crest-like inner wing; maximum lateral extension of inner wing is located more anteriorly in left MI. It differs from Ramphoprion elongatus in having stouter MI, shorter cover in MI, longer shank, less and smaller denticles, and maximum lateral extension of inner wing in left MI, located more anteriorly.

Description. Right MI: Length $0.5-1.1 \mathrm{~mm}$, length/width ratio 2.5-2.6; dentary consists of 14-15 continuously decreasing denticles; ramus extends to $0.62-0.64$ of jaw length from anterior; outer margin between anterior part and tip of ramus is slightly incurved; cover occupies $0.3-0.32$ of jaw length.

Left MI: Length $0.44-1.7 \mathrm{~mm}$, length/width ratio 2.6-2.8; dentary consists of 13-16 smoothly decreasing denticles and is curved outwards anteriorly; outer wing is triangular, its greatest width is located at $0.48-0.51$ of jaw length from anterior; inner wing is long, its somewhat pointed maximum lateral extension is located at $0.51-0.54$ of jaw length from anterior; posterior margin is directed postero-medially and forms $0.46-0.57$ of jaw width; cover reaches to $0.39-0.41$ of jaw length.

Remarks. Männil \& Zaslavskaya (1985, p. 114) cited the specimen No. $738 / 39$ as the holotype. The figures of the type specimen, referred to in the same chapter, display two other specimens, left and right MI (Nos. 738/35 and 738/36, respectively). In the explanation to the figures (ibid., p. 129) these specimens are called holotypes, whereas the data on the specimen No. $738 / 39$ do not contain this notice. However, the holotype of a species must represent one animal (ICZN, 1985, Article 73), that means, it can be one certain jaw plate, unless several jaws are attached, constituting an apparatus. In the present case, three detached jaws, derived by no means from one animal, are marked as holotypes. One of them (left MII No. 738/39) is of uncertain affinity (see discussion below), the second (left MI No. 738/35) does not belong to Ramphoprionidae, but to Polychaetaspidae and only the third jaw (right MI No. 738/36) definitely belongs to Ramphoprionidae. Since the rules of designating a holotype (ICZN, 1985, Article 73) were violated, none of these jaws can be considered as the holotype, but according to Article 74, the lectotype can be selected from the type series (preferring the specimens published by the original author). The right MI No. 738/36, figured by Männil \& Zaslavskaya (1985) in pl. 16, fig. 6b, is appropriate for the lectotype of $P$.? nordicus.

The basal plate (No. 738/41) and the carrier (No. 738/42) figured by Männil \& Zaslavskaya (1985) in pl. 16, figs. $7 \mathrm{~b}$ and $7 \mathrm{v}$, respectively, belong to ramphoprionids, but as two similar species occur in the same samples, they should not be assigned to P.? nordicus. Furthermore, the carrier with its elongated form and tapering posterior part resembles $R$. elongatus rather than P. urbaneki. Männil \& Zaslavskaya (1985) also described two left second 
maxillae (Nos. $738 / 39$ and 738/40, pl. 16, figs. 6d, 7a) which, on the basis of co-occurrence were also assigned to $P$.? nordicus. These jaws differ greatly from those of $P$. urbaneki, but also from other ramphoprionids, in having a very wide outer wing and short shank (cf. Kielan-Jaworowska, 1966, fig. 9). In my opinion, these jaws could not be assigned to a particular ramphoprionid taxon.

Occurrence. Llandovery to late Wenlock or early Ludlow (Vodopad Formation, Golomyannyi Formation, Ust-Spokoinaya Formation); Severnaya Zemlya (Srednii Island, Ushakov River, Stroinaya River, Spokoinaya River).

\section{Pararamphoprion? matusevichi sp. nov.}

$$
\text { Plate, figs. 12-20 }
$$

Holotype. Left MI GI Sc 94; fig. 13.

Type locality. Matusevich River, Severnaya Zemlya, Russian Arctic.

Type horizon. Stroinaya Formation, Ashgill (sample 10-5).

Derivation of name. Named after the type locality.

Material. More than 20 left and right MI and four basal plates from samples 40-1 and 10-5.

Diagnosis. P.? matusevichi sp. nov. is similar to P.? nordicus, but differs from latter in having relatively shorter covers in MI, maximum lateral extension of inner wing in left MI located more posteriorly, and greater number and smaller size of denticles in MI. P.? matusevichi differs from $P$. urbaneki in having more triangular inner and outer wings, less and smaller denticles, undifferentiated dentary in left MI and longer covers in right MI.

Description. Right MI: Length $0.45-1.15 \mathrm{~mm}$, length/width ratio 2.1-3.3; dentary consists of 13-19 very slightly decreasing denticles; ramus reaches to 0.54-0.64 of jaw length from the anterior; anterior portion of outer margin is slightly incurved; cover occupies $0.23-0.32$ of jaw length.

Left MI: Length $0.38-1.12 \mathrm{~mm}$, length/width ratio $2.6-4.0$; dentary consists of 21-26 relatively small, nearly equal-sized denticles and is curved outwards anteriorly; outer wing is subtriangular with its maximum lateral extension at $0.5-0.6$ of jaw length from the anterior; greatest width of crest-like or sigmoidal inner wing is located at $0.6-0.66$ of jaw length; posterior margin forms $0.46-0.65$ of jaw width; cover occupies $0.28-0.33$ of jaw length.

Basal plate: Length $0.3-0.6 \mathrm{~mm}$, length/width ratio 2-2.2; dentary consists of 14-20 denticles, anterior third of them are smaller than posterior ones; inner 
margin is $1.15-1.3$ times longer than outer margin; anterior margin is concave, 1.6-3 times longer than tapering posterior margin; cover reaches to about 0.5 jaw width.

Remarks. Four Ashgillian samples were not taken into account in the paper of Männil \& Zaslavskaya (1985). Although this material is especially poorly preserved, it should be noted that the jaws of $P$.? matusevichi are predominating in these samples. In the Silurian samples, on the contrary, remains of ramphoprionids are rather rare. Seemingly the role of ramphoprionids in polychaete associations has decreased in the Silurian of Severnaya Zemlya, which corresponds to the development of the family in Baltoscandia (KielanJaworowska, 1966; Szaniawski, 1970).

Occurrence. Ashgill (Stroinaya Formation); Severnaya Zemlya (Obryvistaya River, Matusevich River).

\section{Pararamphoprion? sp. A

$$
\text { Plate, figs. 9-11 }
$$

1985 Pararamphoprion nordicus sp. nov. Männil \& Zaslavskaya, pp. 114-115, pl. 16 , figs. $6 \mathrm{v}, 6 \mathrm{~g}$ (partim).

Material. Two right MI from sample 157-4.

Description. Right MI: Length $0.87-0.9 \mathrm{~mm}$, length/width ratio $2.8-3.1$; dentary is curved outwards anteriorly, it has 10-11 longitudinally stretched, rapidly decreasing denticles; posterior $0.25-0.27$ of the ridge is undenticulated; ramus reaches to $0.72-0.74$ of jaw length from the anterior; cover extends to $0.44-0.52$ of jaw length.

Remarks. Two right MI (Nos. 738/37 and 738/38) figured by Männil \& Zaslavskaya (1985) in pl. 16, figs. 6v, 6g (Plate, figs. 9-11 in this paper) differ strikingly from $P$.? nordicus (and also from $P$.? matusevichi and $P$. urbaneki) in having more elongated right $\mathrm{MI}$, shorter shank, longer cover, smaller number and size of denticles, and the presence of long undenticulated part of the ridge and prominent ligament scar in the posterior portion of right MI. These differences suggest that Pararamphoprion? sp. A and P.? nordicus are not conspecific as suggested by Männil \& Zaslavskaya (1985). Further, these species may not be congeneric, but due to insufficient material this question remains unclear.

Occurrence. Late Wenlock or early Ludlow (Ust-Spokoinaya Formation); Severnaya Zemlya (Spokoinaya River). 


\section{ACKNOWLEDGEMENTS}

I am greatly indebted to Mats Eriksson, Peep Männik, Tõnu Meidla, and Prof. Hubert Szaniawski for their kind help and useful comments in improving the manuscript. This study is a contribution to IGCP Project 406 and was supported by grants 1935 and 3516 from the Estonian Science Foundation.

\section{REFERENCES}

Egiazarov, B. H. 1959. Geologicheskoe stroenie arkhipelaga Severnaya Zemlya. Trudy NIIGA, 94 (in Russian).

Eller, E. R. 1942. Scolecodonts from the Erindale, Upper Ordovician, at Streetsville, Ontario. Ann. Carnegie Mus., 29, 241-270.

Eller, E. R. 1945. Scolecodonts from the Trenton Series (Ordovician) of Ontario, Quebec, and New York. Ann. Carnegie Mus., 30, 119-212.

Eriksson, M. 1997. Lower Silurian polychaetaspid polychaetes from Gotland, Sweden. GFF, 119, 213-230.

Hinde, G. J. 1879. On annelid jaws from the Cambro-Silurian, Silurian, and Devonian Formations in Canada and from the Lower Carboniferous in Scotland. Q. J. Geol. Soc. Lond., 35 , 370-389.

International Code of Zoological Nomenclature (ICZN), Third Edition. 1985. International Trust for Zoological Nomenclature, London.

Jansonius, J. \& Craig, J. H. 1971. Scolecodonts: I. Descriptive terminology and revision of systematic nomenclature; II. Lectotypes, new names for homonyms, index of species. Bull. Can. Pet. Geol., 19, 251-302.

Kielan-Jaworowska, Z. 1966. Polychaete Jaw Apparatuses from the Ordovician and Silurian of Poland and a Comparison with Modern Forms. Palaeontol. Pol., 16.

Klubov, B. A., Kachanov, E. I. \& Karatayute-Talimaa, V. N. 1980. Stratigrafiya silura i devona o. Pioner (Severnaya Zemlya). Izv. AN SSSR, Geol., 2, 50-56 (in Russian).

Kurik, E. J., Kurshs, V. M., Markovsky, V. A., Matukhin, R. G., Menner, V. V., Modzalevskaya, T. L., Patrunov, D. K., Samoilovich, Yu. G., Smirnova, M. A., Talimaa, V. N., Khapilin, A. F., Cherkesova, S. V. \& Abushik, A. F. 1982. To the stratigraphy of the Severnaya Zemlya Silurian and Devonian. In Stratigrafiya i paleontologiya devona $i$ karbona (Yuferev, O. V., ed.). Moscow, 65-73 (in Russian).

Männik, P. 1982. Silurian conodonts from Severnaya Zemlya. Fossils and Strata, 15, 111-119.

Männil, R. M. \& Zaslavskaya, N. M. 1985. Silurian polychaetes from northern Siberia. Tr. Inst. geol. geofiz. SO AN SSSR, 615, 98-119 (in Russian).

Menner, V. V., Matukhin, R. G., Kurshs, V. M., Talimaa, V. N., Samoilovich, Yu. G. \& Khapilin, A. F. 1979. Litologo-fatsial'nye osobennosti silura i devona Severnoj Zemli. In Litologiya $i$ paleogeografiya Sibirskoj platformy (Matukhin, R. G., ed.). SNIIGGIMS trudy, 269, 39-55 (in Russian).

Stauffer, C. R. 1933. Middle Ordovician Polychaeta from Minnesota. Bull. Geol. Am., 44, 1173-1218.

Szaniawski, H. 1970. Jaw apparatuses of the Ordovician and Silurian polychaetes from the Mielnik borehole. Acta Palaeontol. Pol., 15, 445-478. 


\section{SEVERNAJA ZEMLJA (VENE ARKTIKA) ORDOVIITSIUMI JA SILURI RAMFOPRIONIIDSETE POLÜHEETIDE REVISJON}

\section{Olle HINTS}

On revideeritud Severnaja Zemlja ordoviitsiumi ja siluri kihtidest pärinevat ning R. Männili ja N. Zaslavskaya 1985. aastal koostatud ramfoprioniidide kollektsiooni. Liigi Pararamphoprion? nordicus Männil \& Zaslavskaya, 1985 holotüübiga seonduvad probleemid on lahendatud sobiva lektotüübi nimetamisega. On kirjeldatud kaks uut liiki, millest ühte (Pararamphoprion? sp. A) käsitleti eelnevalt liigi $P$.? nordicus koosseisus. P.? matusevichi sp. nov. osutus domineerivaks lõugseks polüheediks Ashgilli ealistes proovides. Nooremates kihtides seevastu olid ramfoprioniidid küllalt haruldased, peegeldades sugukonna osakaalu vähenemist siluris (viimast tendentsi on täheldatud ka Baltoskandias). Ebapiisava materjali tõttu on kõigi kolme käsitletava liigi täpne süstemaatiline asend siiani lahtine.

\section{РЕВИЗИЯ ОРДОВИКСКИХ И СИЛУРИЙСКИХ РАМФОПРИОНИДНЫХ ПОЛИХЕТ СЕВЕРНОЙ ЗЕМЛИ (РОССИЙСКАЯ АРКТИКА)}

Представлены результаты ревизии коллекции ордовикских и силурийских рамфоприонид Северной Земли, описанных Р. Мяннилем и Н. М. Заславской (1985). Проблемы, связанные с голотипом вида Pararamphoprion? nordicus, решены выбором надежного лектотипа. Описаны два новых вида - Pararamphoprion? sp. A, ранее рассматриваемого на основе челюстных элементов в составе P.? nordicus, и Pararamphoprion? matusevichi sp. nov., доминирующий среди ашгильских полихет. В более же молодых силурийских отложениях рамфоприониды довольно редки, т. е. доля семейства Ramphoprionidae здесь незначительна (аналогичная тенденция прослеживается в Балтоскандии). Из-за малого количества материала точное систематическое положение трех описанных видов остается открытым. 